\title{
Cloud-Capped Towers: \\ Tectonics in Fibich's Opera Bouře
}

\section{Judith Fiehler}

\section{Introduction}

Analysis is usually based on established patterns that can be viewed objectively. But most of what matters in music is not objective. That is why the academic analytical techniques of the late nineteenth century could not provide satisfactory results for music of the late Romantic era that had proved its worth in performance - for example, for Leoš Janáček's music written after his breakthrough opera, Jeji pastorkyña [Her stepdaughter]. Another way of deciphering these works was needed.

Janáček described the compositional process that had previously been overlooked by analysts. "The art of expressivity in tone, of filling one's consciousness every second, is something that I need. Not a note more or less per second than is admissible to one's vivid imagination. I compose with this sense of proportion and write it immediately into the complete score. To know and have this key to a sense of proportion! Various composers have it (Mahler's tubas!) Káan, (Blodek), Dvořák, Fibich."

The performance practices for such music led to a radical change of focus in Czech musical analysis. Its goal now was to understand the implied, underlying form shaped by the inner coherence of musical sound, providing useful information not only for theorists, but also for performers, listeners, and even other composers. The composer Vítězslav Novák and his circle - particularly the interpreter of his early, experimental works for piano, Václav Štěpán - were leaders in developing this new approach. ${ }^{2}$ Novák's student Karel Janeček combined these results with a generalization of traditional music theory in the 1960 s to form

1 Leoš Janáček, "Komplikační skladba” [The complexities of composition] (1924), in Leoš Janáček. Teoretické dílo = Das theoretische Werk = Theoretical Works, (1877-1927), eds. Leoš Faltus, Eva Drlíková, Svatava Přibáňová, Jiří Zahrádka ([Brno]: Editio Janáček, 2007-8), v. 2, p. 316.

2 The émigré Czech cellist František Smetana (1914-2004) described the underlying assumptions of this approach to me in a conversation circa 1994 in Richmond, Virginia: a composition is only complete when it is brought to life through performance. A successful performance uncovers capabilities of the work, bringing forth aspects that might otherwise be overlooked in analysis; 
a comprehensive new category, tectonics, that could be also applied to earlier music, and could demonstrate the evolution of musical style. ${ }^{3}$

I was interested to find out whether an analysis based on tectonics could find antecedents of Janáček's breakthrough in Czech operas composed in the latter part of the nineteenth century. Fibich's opera Bourre [The Tempest] seemed to be a likely candidate. Fibich had skilfully used extreme dissonance to express expressionistic emotion in Nevěsta messinká [The Bride of Messina] and Hippodamia in ways that were unusually advanced for their era. He was certainly on a path that could have led to his own breakthrough to modernism. But Bouře seems to retreat from that breakthrough.

During the 1890s, Czech opera had a purpose much more important than any compositional breakthrough: defining the Czech community and supporting its efforts to build a sense of Czech nationalism. Perhaps that is why Fibich took a more subtle, one could even say subversive, approach: to experiment with the possibilities of using tectonic capabilities to assume functions of the large form. The dramatic continuity of the operatic genre provided a natural way to achieve this goal.

Shakespeare's play gave him another opportunity. Fibich transforms harmonic functions to produce the illusions of Prospero's magic. Pitch, voicing, and captivating orchestration are flexibly used to emphasize dramatic events as well as declamation of the vocal lines. At times, the music seems to be in free flight, reflecting a magical realm beyond reality.

These techniques produce an inner tectonic form - based on sound, not on theory - that provides the basis for themes, motives, and figurations. Fibich tends to follow the example of Berlioz's idée fixe as it is used in his Symphonie fantastique, reflecting the changing personalities of characters, and supporting the unity of dramaturgy and large form as it unfolds, moment by moment. Like Schumann, Fibich maintains continuity between the inner form and the large form through free interaction between referential elements and his own inspiration. Every note is well considered, precisely in the right place.

the work itself grows as these performances accumulate. A successful analysis does not merely establish facts about the work; it provides the keys to unlock its possibilities for performance.

3 The term tectonics is authoritatively discussed in textbooks by Karel Janeček (1903-1974), particularly his Tektonika (Praha, Bratislava: Editio Supraphon, 1968), and summarized in the chapter "Dosah a poslání hudebních analýz" [The scope and mission of music analysis] in his final publication, Smetanova komorní hudba: kompozični výklad [Smetana's chamber music: compositional interpretation] (Dílo a život Bedricha Smetany, vol. 1) (Praha: Supraphon, 1978), 27-33. This term is used in Czech music theory to describe analytical inference of the inner structure and connective tissue of a composition. 


\section{Large Form: Sonata Allegro}

The prolific musicologist Jiři Vysloužil discovered an important analytical concept when studying the evolution of Janáček's vocal style: mutations of the structural properties of large form, and the relationship of large forms to inner tectonic forms, can be significant in the development of new musical discourses during eras of major stylistic change. ${ }^{4}$

Beginning in the 1870s, Fibich and other Czech composers sought to develop a national musical discourse by balancing large form and tectonic layers in symphonic poems based on Shakespearean subjects. Smetana skilfully responded with his České tance [Czech dances] $(1877,1879) .{ }^{5}$ This work not only presents a model for a national musical discourse based on this balance; it utilizes traditional Czech folk dances to communicate directly with the listener. Like Chopin, Smetana uses daring pitch structures to give depth and brilliance to the virtuosic flourishes and transitions that interrupt the large form, discovering a more universal way to reach the audience than the logic of classic form. Momentum is sustained by characteristics of the dance music genre: a consistent metric pattern, steady rhythmic pulse, pattern, and intuitively clear voice-leading. The focus shifts from large form to dancing itself, to the immediate moment. Extensive passages in Dupák, Skočná, and Obkročák consist only of patterns and shifting modulations.

Bouře is written in expanded sonata allegro form. However, Fibich deliberately transferred most of the traditional weight and structural properties of the large form to tectonic layers based on sound itself. As these layers gain strength and independence, they undermine the traditional unity of periodic form, melody, and harmony. Melodies no longer fall into neat, coordinated segments. Harmonic progressions no longer drive to cadences, not only raising the question of their value in this new context, but of tonality as well. Increased flexibility enables the composer to follow his inspiration; to discover new patterns for achieving continuity; and to introduce new material imaginatively. These techniques had enabled many Romantic composers to convey a stream of consciousness - sometimes along with extramusical references - to evoke a spontaneous, intuitive audience response. In Boure, Fibich use them to achieve a fundamental compositional breakthrough that extends far beyond mere dissonance.

But the large form still anchors the composition. Like Schumann, Fibich retains the properties of large form that are advantageous to him: continuity by controlling related spans of time; pacing; contrast; control over the positioning

4 Jiří Vysloužil, "Ke vztahu slova a tónu u Dvořáka a Janáčka” [Toward the relationship of word and note in the music of Dvořák and Janáček], Muzikologické rozpravy (Praha: Panton, 1986), 95-100.

5 Jiří Kopecký, "The Birth of Czech National Music: Young Composers and Their Love for Shakespeare." Unpublished typescript. 
of climactic moments; interaction with the tectonic inner form. The sections of the large form are principally defined by moods that provide a secure context for referentiality and dramatic events.

At first glance, Shakespeare's The Tempest does not seem suitable for a late Romantic opera. The earliest surviving text appears to be in the form of a masque with elaborate stage effects and incidental music. ${ }^{6}$ It is too short to provide a full evening's entertainment. It consists of relatively static tableaux and lacks sustained dramatic urgency. To create a suitable opera libretto, Vrchlický and Fibich heightened the dramaturgical force of the original text by giving greater depth to characterizations, expanding the plot, revising scenes, and emphasizing theatrical effects. Fibich's Prospero is not the enlightened sage seen in traditional productions of The Tempest. In Boure, his will to seek revenge provides momentum to the tectonic layer.

Vrchlický and Fibich enhanced the theatrical pacing of the libretto by adapting it to sonata allegro form. The three acts of Boure can be clearly identified as exposition, development, and recapitulation with coda. ${ }^{7}$ Its four thematic areas correspond to the principal characters. Substantial changes were made to support the unity of large form and dramatic plot. Here are a few examples of the most important changes.

The overture serves as the introduction of the sonata allegro form. It begins the action by depicting the tempest itself, providing a level of excitement and suspense that immediately engages the listener's attention. The section in which Fernando and Miranda meet and fall in love is significantly expanded. It gradually increases from tranquility to passion, and then to Prospero's simulated anger, providing a forceful end to Act I.

The "vanishing table" scene in The Tempest ends with Ariel (under Prospero's off-stage direction) scolding the noble company for their misdeeds. This scene continues to escalate in Bouře. Prospero makes a spectacular entrance in his magician's robes, exacting revenge and forcing the nobles to kneel before him. His triumphant exit - almost an apotheosis - provides an appropriate climax to the development section, and a memorable finish to Act II.

6 Frank Kermode, ed., The Tempest (The Arden edition of the works of William Shakespeare) (Cambridge: Harvard University Press, 1958) (sixth edition), p. xxii, xxiv, 150-5. All references to the text of Shakespeare's play were verified against this publication. This book contains meticulous annotations of the text, and a wealth of scholarly information about the play.

7 It may be relevant that the overture to Die Zauberflöte is in sonata allegro form with three themes and an expanded recapitulation, and that its dramatic form consists of exposition, development, and resolution. The overture to Weber's Oberon can also be analysed as a sonata allegro form with three themes. However, the second theme, the well-known clarinet solo, is reprised in the development section rather than the recapitulation. 
Act III presents a dramatic resolution of the tectonic form as well as the plot. The principal characters appear, in reverse order of their appearance in Act I: the sonata allegro form has been modified so that it can also be analysed as an arch form (palindrome).

The "chess scene" in which Fernando and Miranda prove the worth of their love is merely a line in The Tempest; here, it has significant dramaturgical length and weight within the sonata allegro form. Kaliban's reprise, the conspiratorial trio, is significantly shorter but much more intense; Ariel's entrance is less than a page, but it represents an entire scene from Shakespeare's text that must have been spectacular in performance, the Act IV finale: at Ariel's command, the hounds of hell chase Kaliban and his friends, defeating their plot to murder Prospero. The recapitulation ends with Prospero's lengthy metamorphosis from a "magician-artist to an artist-man," ${ }^{8}$ and ends with a cadence, a signal that Prospero has renounced his magic (Maestoso, p. 201, system 6).

The coda begins as the major characters make peace with each other; their motives are resolved as well. As the humans prepare to leave the island, the music becomes solidly conventional - they are returning to reality. Ariel's music has a second, more important reprise in the coda as spirits gain their freedom.

A very few motivic groups appear in all three acts and are reprised in the coda. I identify them as the four principal "themes" of the exposition, referring to Prospero, Ariel, Kaliban, and the love of Fernando and Miranda. Subsidiary material, also structurally important, can be identified with Prospero's will; the relationship of Prospero and his brother Antonio; and the spirit chorus. This material appears in Act I, is developed in Act II, and is resolved in Act III.

These groups and their interrelationships represent only a small part of the analysable material in Bouře.

\section{OUTLINE OF SONATA ALLEGRO FORM}

ACT I. EXPOSITION, p. 4-79

Overture p. 4-7

Prospero and Miranda, p. 8-23; 36-39

Prospero and Ariel p. 23-35

Prospero and Kaliban p. 40-46

Ship's company misled by Ariel p. 47-65

Ariel, Fernando, Miranda, later Prospero p. 65-79

8 Zdeněk Nejedlý, Zdeňka Fibicha milostný deník [Zdeněk Fibich's diary of love] (Praha: Melantrich, 1948), 275. 
ACT II. DEVELOPMENT, p. 80-145

Introduction, p. 80-81

Fernando, Miranda, later Prospero, p. 82-98

Kaliban, Stefano and Trinkulo, p. 98-113

Ariel and ship's company, p. 113-130 (vanishing table scene)

Prospero enters majestically and pronounces judgement, p. 130-145

ACT III. RECAPITULATION, p. 146-217

Introduction, p. 146-153

Prospero, Ariel, p. 153-165

Fernando and Miranda, p. 158-165; p. 165-181 (chess scene)

Kaliban, Stefano and Trinkulo; Ariel, p. 182-190

Prospero's transformation, p. 191-201

CODA p. 201-217

Reprises and plot resolutions, p. 202-205

Prospero frees Ariel, p. 206-211

Choruses of humans and spirits, p. 212-217

\section{Motives and Figurations}

More than forty passages in Boure have been identified as significant by various authors. Most of them belong to groups of characteristic musical material representing characters, and subsidiary material that represents continuing action. Each group has its own characteristic style, and its own method of development or transformation. I have identified four thematic groups that are clearly related to principal characters, and are strongly related to the sonata allegro form. They are shown here in the order that they appear in the exposition.

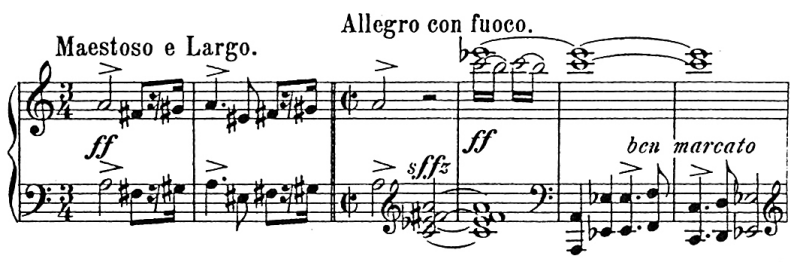

Example 1: Prospero's motive ${ }^{9}$

9 Carl Ludwig Richter (pseudonym for Anežka Schulzová), Zdenko Fibich: eine musikalsche Silhouette (Prag: F. A. Urbánek, 1900), example 1; Jiří Kopecký, Opery Zdeňka Fibicha z devadesátých let 19. stoleti (Olomouc: Palacký University Press, 2008), example 20; Jaroslav Jiránek, Zdeněk Fibich (Praha: Akademie múzických umění, 2000), example 1. Bouře, vocal-piano score, p. 7, last three systems (bass), end of overture to Act I. Zdeněk Fibich, Bouře: Zpèrvohra o 3 jedináních, baseñ dle sujetu stejnomenné dram. pohádky Shakespearovy napsal Jaroslav Vrchlický = Der Sturm: Oper in 
Prospero's strength and determination are revealed in the Beethoven-like developing variation of his motive. This is the only motive in Bourre that seems to behave consistently like a Wagnerian leitmotif (literally, leading motive); it can cut through any tonal context like a knife. It appears from scene to scene throughout the opera, enabling us to perceive the opera from Prospero's viewpoint.
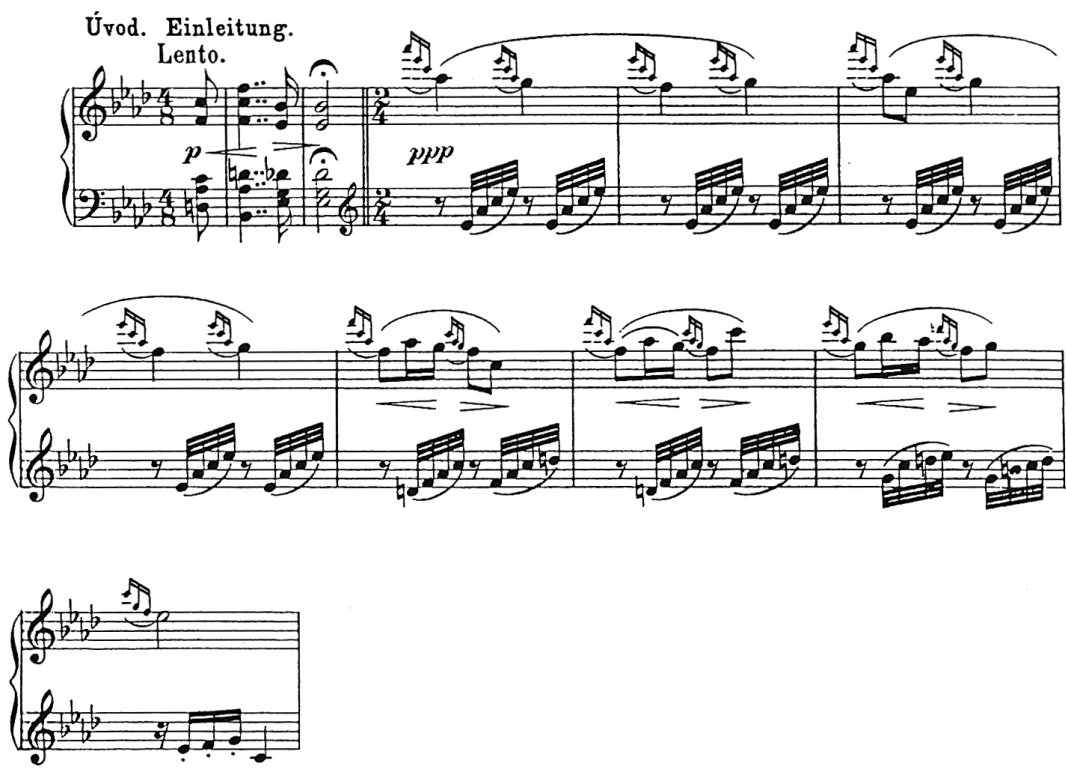

Example 2: Ariel's motive ${ }^{10}$

This passage does not develop as a motive, but as a mood, providing a context for the spirit chorus as well as for Ariel. It gives the listener a more primal sensation than conventional music could provide, through a web of figurations and timbre.

3 Acten, Gedicht ach de Sujet des gleichnamigen Märchens Shakespeare's von Jaroslav Vrchický, op. 40. Vocal-piano score. Praha: Fr. A. Urbánek. Overture, p. 7, sixth system. This motive is developed, for example, on p. 138, as Prospero brings his enemies to justice; resolved on p. 196, fifth system, as Prospero prepares to leave the island.

${ }^{10}$ Kopecký, Opery, example 25; Jiránek, example 4. Bouře, vocal-piano score, p. 146, beginning of the introduction to Act III. The fact that its incipit resembles the incipit of the Toccata from CharlesMarie Widor's Symphony no. 5 (1880) suggests that Fibich may have continued his interest in French music after his sojourn in Paris (1868-9). Richter, example 2, shows the arpeggios that often accompany Ariel. 
Ariel's music reflects his obedience to Prospero in a two-note characteristic motive that moves the plot forward according to Prospero's commands. This motive may not have been previously identified. ${ }^{11}$ Depending on the situation, it is a rising or falling fourth, fifth, or octave; the interval of a perfect fourth is a generative element throughout the opera. Ariel's music comprises the second thematic group.

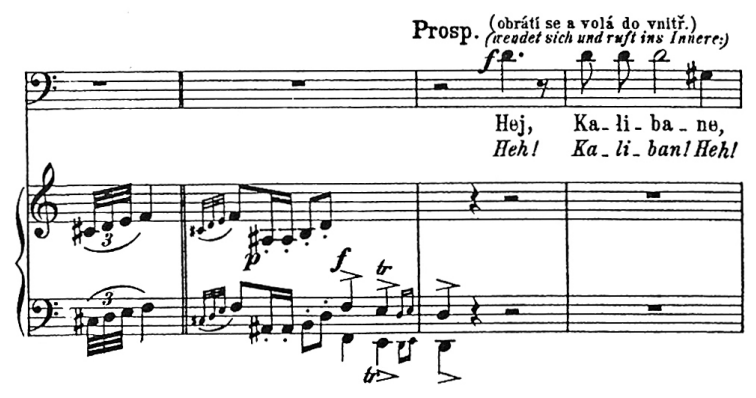

Example 3: Kaliban's motive ${ }^{12}$

Kaliban's bitter, aggressive motive consists of a single, unchanging bar. Even when he submits to Prospero, his spirit is inwardly defiant. This motive is often surrounded by accompanying, volatile figurations that describe the antics and reactions of the Shakespearean clowns Trinkulo and Stefano. ${ }^{13}$ His rebellious nature bursts forth when he expresses his intention to murder Prospero. ${ }^{14}$ Its stubborn, independent vocal line reflects spontaneous vernacular speech. Frag-

${ }_{11}$ This brief motive, also appearing in inversion, fifth, and octave, may be a quotation from Smetana's Hubička, Act II, opening of scene 1, the chorus of Matouš and his band of smugglers, "Jen dál!" [Come on!] Bouře, "Zdar, mistře můj! [Live well, my master!] p. 23, first system, Ariel; “Ted” sem, jen dál." [Here, come on]. p. 58, first and second systems. These leaps are expanded and elaborated in Ariel's transition to the vanishing table scene: "Jaký hlmoz, jaký hřmot ... Úkol můj jest ukončen" [What noise, what a clatter ... My task is done], which begins on p. 188, second system and continues on p. 190, third system.

12 Richter, examples 7, 11; Kopecký, Opery, example 32; Jiránek, example 5. Bouře, Piu lento, introduction to Kaliban's aria, "Mor, na vás oba, stále sloužit jen!" [A plague on you both, nothing but endless service!] p. 41, first system. "Tiše, tiše, hoši milî" [Quiet, quiet, dear fellows], p. 98, last system. "V bahně já se v slunci válel" [I wallowed in mud, in sunshine], p. 100, last system corresponds to Richter's example 7; p. 182, third system, "Po špickách!” [On tiptoe!].

${ }^{13}$ Richter, p. 159, confirms this interpretation. In a January 1945 Broadway production of Shakespeare's Tempest, these roles were played by Jiří Voskovec and Jan Werich respectively. Jiři Voskovec E' Jan Werich: Korespondence I, Ladislav Matéjka, editor ([Praha]: Akropolis, 2007), 11.

14 “Nuže, slyšte, tajný plan ted' zjeví Kaliban” [Now listen, Kaliban will reveal a secret plan], beginning on p. 108 , second system. 
ments from his motive and accompanying figurations are developed in this aria. This stylization is expanded in Act III when Kaliban, Trinkulo, and Stefano try to carry out their rebellious plot. ${ }^{15}$ The group consisting of this motive and its associated figurations functions as the third theme.
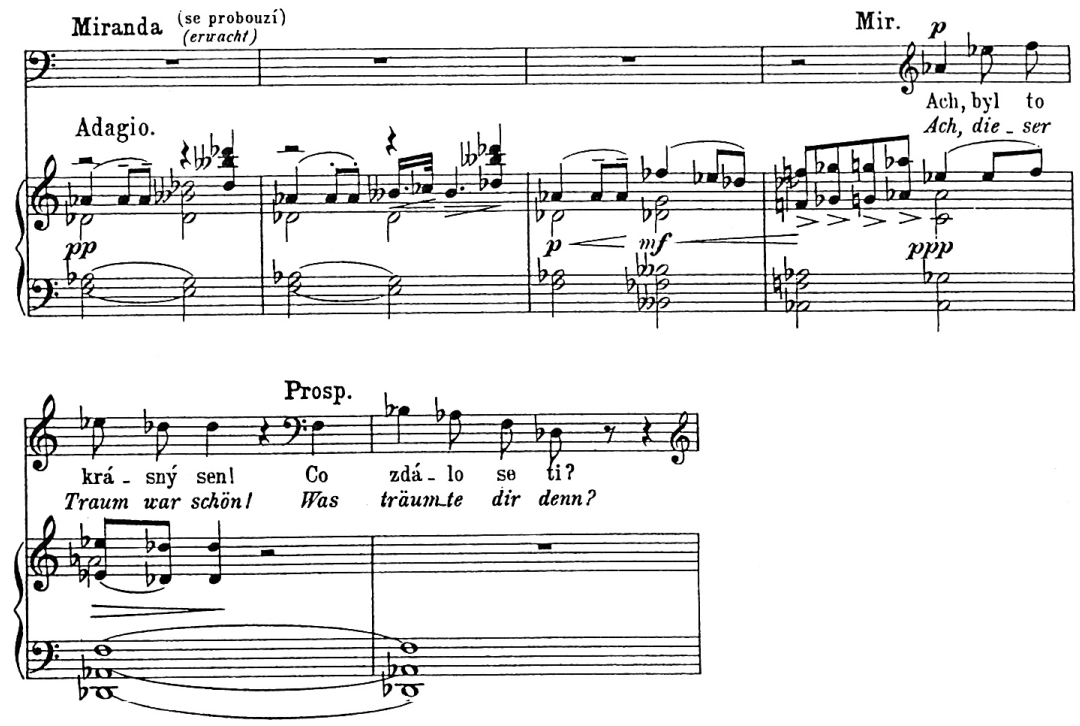

Example 4: Motives of Fernando and Miranda ${ }^{16}$

The music of Miranda and Fernando displays another developmental technique. A simple phrase generates a wealth of lyrical melodies. ${ }^{17}$ These melodies are often based on triads; they freely unfold, revealing rather than generating the duet-dialogues of the lovers, culminating in their duet at the end of the chess

15 According to Richter p. 169, the passages in Acts II and III were deliberately written in Italian opera buffa style. She supports this statement with her example 19, the accompaniment to "jak jsme vytáhli jej z lodě” [as we dragged him out of the boat], Bouře, p. 184, first system.

${ }_{16}$ Miranda awakens from a dream of Fernando, “Ach byl to krásný sen!” [Ah, that was a beautiful dream], Richter, example 7; Kopecký, Opery, example 10; Jiránek, example 2. Bouře, p. 36, first system, Adagio. Introduction to Fernando's first meeting with Miranda, Richter, example 5; Kopecký, Opery, example 17; Jiránek, example 3. Bouře, p. 65, second system, L'istesso tempo. Introduction to the scene in which Miranda and Fernando meet.

17 “Jak nyní tebe na své srdce vinu!" [Now I can enfold you to my heart!"], Bouře, p. 178, first and second systems. 
scene, when they have successfully proved their love. ${ }^{18}$ The rising fourth associated with Ariel begins the music for their first sight of each other, revealing how Fibich links the motives of the opera. The fourth expands to the outline of a first inversion chord, another germinating motive for this group. Fibich's use of this technique reveals his gift of finding inspiration for extraordinary music in simple material. The extensive group of graceful melodies that express the love of Fernando and Miranda comprise the fourth theme.

The subsidiary material consists of fragments that are transformed throughout the opera as they reveal the course of the plot. Here are a few examples.

Repeated notes and chords, particularly triplets, that may represent Prospero's emotions: This fragment may derive from the first three notes of the Prospero motive. It first appears in Act I as Prospero tells Miranda how they came to the island. ${ }^{19}$ In Act II, it progressively develops to fortissimo chords as the illusion of a table laden with delicacies vanishes before the eyes of the hungry humans; emphatic repeated accented notes signal Prospero's entrance and exit. ${ }^{20}$ This fragment is augmented to produce the solemn chords that accompany Prospero's judgement, beginning in Act II p. 132, third system, and also the pseudo-cadence that accompanies Kaliban's statement "Pak já budu pán a král!" [Then I will be lord and king!] in Act II, p. 111, first system. It reappears in the Maestoso cadence (resolving to the subdominant) that ends the recapitulation (p. 201, last system). Its last appearance is another cadence, finally resolving to the tonic, ten bars before the end of the opera.

18 According to Kopecký, Opery, footnote on p. 143, Vladimír Hudec identifies this process with the German term Fortspinnung. Kopecký finds an antecedent for this technique in Fibich's symphonic poem Boure. It is used extensively as a unifying factor in Tchaikovsky's Eugene Onegin, successfully performed in Prague in 1888. According to Kopecký, Opery, footnote 164 on p. 117, it is a vital generative technique in Suk's Asrael, Zráni, and Epilog.

19 It first appears in Bouře as triplet quavers followed by a crotchet on p. 11, first system, just before Prospero explains to Miranda, "Tu bouři stvořilo mé umění" [This storm was raised through my art]. It appears as a repetitive pattern, two quaver notes and a crotchet on p. 51 (the entire page), accompanied by a chromatic descending line in the bass that spans a diminished fifth at the end of the complaint by the ship’s company, "kde pláň zívá ale nikde člověka!" [where there are wide open spaces, but not a single person!"].

20 Richter, examples 14 and 12 (spirit chorus); Kopecký, Opery, example 16 (end of the opera). Boure, notably p. 127, second system, along with thunder, Ariel enters and the table vanishes. The fragment finds resolution on p. 197, third system, in three pianissimo chords preceding Prospero's aria "Vy duchové, již sluje obýváte" [You spirits who live in the grotto], Bouře, p. 197, third system. 
Melody and bass in contrary motion, representing the discord between Prospero and his brother Antonio: ${ }^{21}$ As they gradually become reconciled, these voices gradually move toward agreement.

Motivic fragments representing pointless efforts by the ship's company to cope with magic:22 They are rarely identified with individual characters.

Magical figurations and evocative sounds associated with the spirit chorus, resembling Ariel's music: ${ }^{23}$ In the scenes with the ship's company, the spirit chorus observes the situation with detached amusement. At Prospero's direction, spirits tempt Fernando and Miranda to kiss instead of playing chess.

Each group of motives and subsidiary material has its own characteristic tectonic properties that respond to our imagination rather than logic. Thus, subjectivity is unavoidable - but that is an advantage, not a problem. The potential for multiple interpretations only adds to the treasures that Boure provides for the listener and analyst.

\section{The Inner Tectonic Form}

In Nevěsta Messinka and Hippodamia, Fibich accompanies declamation with an inner tectonic form resembling recitative. It is a continuous mirror of dramatic action and emotion; motives give it coherence. That technique is the point of departure for the tectonic forms in Boure.

Unexpected changes of direction are possible within the musical current. When a chord sequence no longer leads to a cadence, it can be driven by a variety of other factors; the current becomes a stream of mature, supple chromatic harmony. Many early Romantic works display such a current; for example, the development section of the first movement of Schubert's Sonata in Bb major, and the last section of Schumann's Symphonic Etudes. An irresistible tectonic current

21 “Můj bratr dobrotý mé zneužil, strh na se vládu, trůn mi ulopil.” [My kind-hearted brother abused me, rose to power, usurped my throne], Bouře, p. 13, third system. See Richter, example 9; Kopecký, Opery, example 26; Jiránek, examples 6 and 7. Introduction to Prospero's aria "Tak ostrove můj, sbohem" [Farewell, my island] p. 192, third system, Maestoso. Reconciliation of Prospero and Antonio, p. 202 "Ty bratře odpouštíš?" [Do you forgive your brother?] p. 202, third system.

${ }^{22}$ Kopecký, Opery, example 8. Bouře, p. 61, last system. The laughter of the spirit chorus in Bouře may echo the laughter of the Elfenchor in Weber's Oberon. Other possible models for Fibich's spirit music could have been Mendelssohn's incidental music to Shakespeare's A Midsummer Night's Dream and the Queen Mab aria from Gounod's Roméo et Juliette.

${ }^{23}$ Ship's company, beginning on p. 47, fourth system: "Ostrov plný vděků luzných" [Island full of felicitous delights]. Chess scene, Allegretto non tanto: "Hle, jak její ručka bílá na prknose položila" [Look how she puts her white hand on the chessboard], p. 166, third system. 
propels the finale of Dvořák's Symphony no. 8 , as well as dramatic scenes in the second act of Berlioz's Les Troyens and in Verdi's Otello.

The effect of dissonance can be altered by voicing, articulation, and instrumentation. Its role can range from a mere coloration, ornament or spice to intensification of other musical aspects - particularly the momentum of the passage. Such techniques are particularly suitable for the magical effects in Boure, and the wide variety of declamatory styles of its characters.

Moods help define the large form. Tonality becomes a generalization of relationships among programmatic elements, among clusters of mood, tonalities, and referentiality associated with the major characters. Motives and motivic development, cleverly devised to amplify the essence of these characters, replace the traditional thematic structure. As in Beethoven's music, these elements are brought to the foreground to mediate with the other compositional aspects of the work; but here, they increase the weight of the tectonic layer rather than reflect the large form. The distinction between compositional genres, which Fibich usually observed, recedes as his own musical impulse gains importance. This trend can be observed in other later Romantic operas, but it appears in Bouře with unusual clarity.

Bouře marks the early stages of an important turning point in Czech music: the emergence of tectonics as a layer in its own right, as the immediate, unmistakable, unfettered expression of the composer's will.

Fibich's mastery is shown in a compositional tour-de-force: the Adagio leading into the coda, beginning on p. 200 , last system. In only 26 bars, this passage progresses seamlessly from an atonal canon to analysable harmony, then to a melody whose tonality is given only by the accompanying triplet chords, developing to a passionate peak and finally to completely tonal lyricism. It prepares a fortissimo cadence that would be fully conventional except for its resolution. The cadence ends with the progression of a dominant seventh to a subdominant chord rather than to the tonic, signalling that the opera is not over. It leads to the beginning of the coda, and the turn from magic to reality.

\section{Implications for Pitch Structures}

Fibich's path between consonance and dissonance may have been inspired by free chord-progressions in the piano music of Robert Schumann. Fibich uses chromaticism, coloration and modulation for dramatic effect, along with ambiguous tonalities that are deceptively diatonic to portray the effect of magic. Chordprogressions can be based on free and common note modulation; voice leading can be based directly on scalewise and chromatic intervals. Doubly diminished, 
altered, and other unusual chords enable unexpected modulations which, in turn, can be shortcuts to a variety of options.

Melodic lines are often sharply inflected, enabling text to take priority as a vital semantic force. Freely chosen chords and intervals are outlined in progressions that do not resolve. Rising and falling lines are paced by melodic span, leap, scales, rhythm, and most importantly by chromatic notes that are fully integrated with the harmonic level; for example, a rising line with sharpened notes or rapid chromatic scales may have an accelerating effect.

The result is a flexible, not entirely tonal layer that is relatively independent of the formal structure. Fibich has not taken a path to atonality, but to extending and enriching tonality, highlighting the results through subtle orchestration.

Certain pitches and tonal centres seem to have a specific meaning in Boure, just as keys have a specific meaning in Zauberföte and Dalibor. Here are a few examples.

The major triads on $\mathrm{Eb}$ and $\mathrm{G}$ seem to act as tonal anchors in music connected with Prospero's magic; Eb provides its sense of direction; $G$ indicates its successful outcome. ${ }^{24}$

$\mathrm{Ab}$ key-signatures with the marking Maestoso indicate actions by Prospero that are strongly connected to the large form. A is associated with their resolution, and also with the real world. ${ }^{25} \mathrm{Ab}$ and $\mathrm{A}$ major are important keys in the duets of Fernando and Miranda. ${ }^{26}$

$\mathrm{Ab}$ is the prevailing key in the introduction to Act III, setting the scene in which the lovers attempt to play chess despite distractions from the spirit cho-

${ }^{24}$ For example, Bouře, p. 20, second system, after Prospero angrily describes his brother's treachery: "mně hvězdy samy předpisují cestu!" [My stars direct my path!] Eb major triad (Sarastro's key in Zauberflöte) on "hvězdy" (stars), G major triad on "cestu" (path). In the coda, p. 206, second system, as Prospero gives Ariel his freedom, “Ty duchu můj ... svou volnost měj!” the text is set to the outline of an Eb7 chord up to "volnost," which is accompanied by a $\mathrm{G}$ major triad. Prospero's last words to Ariel are "Zdráv Ariel!" set to Eb - G, p. 209, third and fourth systems.

${ }^{25} \mathrm{Ab}$ : Prospero's judgement: "Vy znáte všichni velkou cinu svoje a nyní nastal msty a trestu čas!" [You are aware of all of your great guilt, and now is the time for revenge and punishment!" beginning on p. 131, fourth system; also the aria "Vy duchove," [You spirits], p. 197, third system. The key of A major accompanies the departure of the humans: "A nyní $\mathrm{k}$ břehu, korab čeká" [Now to the shore, the ship is waiting], p. 212, first system, Allegro moderato.

${ }^{26}$ Prospero anticipates the use of $\mathrm{Ab}$ for Miranda’s characteristic motive in "O spi! Ten dušný vzduch pln vưně opíji!" [Go to sleep! This slight breeze filled with fragrance is intoxicating!], p. 21, first and second systems. In Miranda's awakening from a dream of Fernando: "Ach, byl to krásný sen" [That was a beautiful dream!]; the first note is $\mathrm{Ab}$, and $\mathrm{Ab}$ is the common note of the cadence that accompanies the phrase, on p. 36, beginning in the first system. A is used as a pedal note in the Act II entr'acte (page 80), setting a realistic scene for Fernando's yearning solo in Ab: "Však ona je tak spanilá a milá" [She is so fair and lovable], on p. 83, beginning of the last system, Moderato. When Miranda enters, she also sings in Ab: "Zas se tak těžkou prací namáháte a k čemu?” [Why do you bother with such hard work, and for whom?] on p. 87, third system. 
rus. The chess scene begins and ends in $\mathrm{Ab}$. F major is the key of resolution for Miranda and Fernando, and is the final chord of the opera.

$\mathrm{D}$, the first note of Kaliban's motive, is at the interval of a diminished fifth from $\mathrm{Ab}$, evidently revealing his dislike of Prospero. ${ }^{27}$

\section{Related Operas: Conclusion}

Some of Bouře's remarkable stylistic traits can be found in operas by Fibich's Czech contemporaries, especially regarding tectonic form, mood, expressive declamation, and expansion of tonality. We will concentrate on three of the best-known operas: Smetana's Dalibor, Dvořák’s Rusalka, and Janáček's Jeji pastorkyña. ${ }^{28}$ All four operas have a remarkable feature in common: a deliberate balance between innovation and dramatic effect, achieved by an excellent composer at the peak of his powers.

All four operas begin with a strong, dramaturgical mood that provides the context for the characters and their situations. The introduction to Dalibor reveals that Dalibor is in great danger. The overture to Boure begins with the storm that Prospero has invoked through magic, setting the plot in motion. The overture to Rusalka expresses the sadness that the heroine will endure by leaving her lake for a false reality. In Jeji pastorkyña, the first few bars convey the unavoidable reality of the mill, soft twilight after a long day, and Jenưfa's hope for a better life. In all four operas, an unbroken sequence of such moods carries the dramaturgical weight of the large form. The personal musical discourse of the composer mediates between these moods and the events of the plot.

Rhetorical techniques of sacred music for depicting emotions, moods, and aspects of reality are evident in these operas. The power of the Act II judgement scene in Boure reflects traditional settings of the Credo and Dies Irae. Dalibor's

27 Prospero calls Kaliban with this interval, beginning on p. 39, last system: “Hej, Kalibane! ... Ven z doupěte" [Hey, Kaliban ... come out from the earth]. Kaliban answers with the same interval. The diminished fifth interval seems to be associated with Kaliban; for example, "mne hladil jsi a šimral az ušima" [You stroked me and tickled me behind my ear], p. 43, second system.

${ }^{28}$ In this section, I refer to the following vocal-piano editions:

Dalibor: zpevohra o trech jednánich. Slova napsal Josef Wenzig. Hudba složil B. Smetana. [Dalibor: opera in three acts. Libretto by Josef Wenzig. Music composed by B. Smetana] (Praha: Nákladatel Družstva ctitelů Bedřicha Smetany, 1884).

Rusalka: lyricá pohadka o 3 jednánich / sepsal Jaroslav Kvapil / Deutsch von Josa Will / Zubudebnil Ant. Dvoŕák = Rusalka: lyrisches marchen in 3 acten von Jaroslav Kvapil / Deutsch von Josa Will / Musik von Ant. Dvořák [Rusalka: lyric fairytale in three acts / written by Jaroslav Kvapil / translated into German by Josa Will / music by Ant. Dvořák] (Praha: Umělecká beseda, 1910).

Leoš Janáček. Jeji Pastorkyňa (1896-1911) / Opera o trech jednáních dle dramatu z venkovskébo od Gabriely Preissové. [Her Stepdaughter] (1896-1911 / Opera in three acts according to the play about country life by Gabriela Preissová.] (Praha: Umělecká beseda, 1917). 
canon seems to depict mourning, for it is based on a fragment of Zdeněk's melody. These techniques also intensify the emotional content of Rusalka. Most importantly, they contribute to the solid tectonic foundation of Jejipastorkyna; at times, the meaning of the text is depicted almost literally in its accompaniment.

The major actors in these operas are characterized by musical traits that are not necessarily motivic. These traits tend to be similar for similar personalities. The most obvious example is the music of the dynamic antiheroes: Dalibor, Kaliban, Vodník and Ježibaba, Laca and Kostelnička. They are complex personalities, neither good or evil. Like the stereotyped villains of French grand opera, the range and depth of their dramatic expressivity are intensified; their theatrical effect contrasts with that of the other characters. Their music tends to be turbulent, nonharmonic, dissonant, and atonal; it communicates through sound itself. The atonal polyphonic passages associated with Dalibor and the twisted contours of Kaliban's music are psychologically revealing; Kaliban's stubborn, rough vocal lines may anticipate Laca's outbursts. Dissonance and clever voicing accentuate the scary fascination of Ježibaba's magic; Vodník's vocal lines struggle, like Dalibor's polyphony, within strict limitations. The masterful use of dissonance in Jeji pastorkyña comes to a climax in Kostelnička's murderous aria "Co chvíla," and the scene in which the baby's body is discovered.

As Prospero abandons magic, the Adagio leading to the coda moves from atonality to a conventional cadence. Dalibor's music is transformed to traditional harmony when he finds Milada and picks up the violin. The music associated with Rusalka and the prince becomes tranquil as they find peace together.

Boure and Rusalka are especially close, partly because they are both fairytale operas. The large form of Rusalka can be analysed as a three-part ABA form; the reprises in the third act correspond, for the most part, to events in the first act. Both operas display a striking unity of large form and inner structure. The portrayal of the realm of spirits is orchestrated similarly in Rusalka and Bouře.

In contrast, the musical discourse of Jeji pastorkyna is shaped by a deliberate attempt to create an authentic national style. Periodic form is restricted to folk music and Jenůfa's prayer. Sustained mood has replaced formal design. The strong musical current controls the psychological course of the drama, accurately conveying the harshness of life in a folk village of that era. The vernacular text is set according to approximations of the words as they are spoken; the sound and emotions of these words are also reflected in other aspects of the music. In the orchestra, pitch can be used as signal as well as dramatic emphasis. Imbedding these techniques in a strong tectonic form gives the opera its distinctive shape. 
The basic cell of the dodecaphonic canon from Dalibor links all four operas. ${ }^{29}$ The canon is based on a three-note cell consisting of a minor third containing a major second - the first three notes of the minor scale. This cell is prominent in atonal polyphonic passages that reveal Dalibor's unyielding, unconquerable nature. The incipits of the significant themes in Rusalka are based on this cell; it can be traced extensively in Rusalka's tectonic form. ${ }^{30}$ The first music we hear in Jeji pastorkyña, the sound of the mill, ends with this cell, and it is immediately repeated in all of the three phrases that follow. ${ }^{31}$ Janáček freely alters and expands the pitch content of this cell, in much the same way as the interval of the fourth is treated in the music of Fernando and Miranda. Prospero's motive is based on this cell. In the other three operas, this cell often depicts unavoidable reality.

The harshness of that cell is balanced by the gentle beauty of nature. Boure and Rusalka have similar music for the realm of spirits - simple chords, often orchestrated with woodwinds and harp. In Jeji pastorkyña, genuine feeling is the birthright of the village people. ${ }^{32}$ In Dalibor, the hunting horn harmony of Zdeněk's theme directly evokes nature; the harp is associated with Milada, who brings peace to Dalibor. ${ }^{33}$ Hope and love are expressed in lyrical, diatonic arias that generally reflect the composer's ingenuity rather than operatic tradition. ${ }^{34}$

Although some direct influence can be traced among these operas, some of these similarities undoubtedly result from trends of the historical era. For exam-

${ }^{29}$ Dalibor, p. 1, bars 16-23, as the curtain rises.

${ }^{30}$ Perhaps its most obvious appearance is in Vodník's aria "Celý svět nedá ti” [In the whole world, there is nothing that can help you] (Rusalka, Act II, p. 131, first system).

${ }^{31}$ Act I, page 1, second system ff. The theme of the chorus "Každý párek musí svoje trápení přestát" [every couple must endure suffering] (Jeji pastorkyña, Act I scene v, p. 68), is based on this cell. The cell appears in Kostelnička's aria "Co chvila” (Act II scene v, beginning on p. 154) at "jak so všecko stoji” [That's how matters stand], Ibid., p. 159), again an expression of resignation; in Act II scene viii, at “... učinila dobře" [I have done well], p. 196, but the minor third is filled in chromatically at "Běda jemu i mně!" [woe to him and to me!] (Ibid., p. 199).

${ }^{32}$ Jenůfa's prayer, “Zdrávas královno, matko milosrdenstvi” [Mary, Queen of heaven, merciful Mother] (Jeji pastorkyña, Act II, scene vi, beginning on p. 175), and the wedding folk song that her friends sing for her, "Ej mamko, mamko, maménko moja!" [Ah, mama, my dear mama!] (Act III, scene vi, p. 238-9).

33 Dalibor, Act I, scene iv, p. 42, "Slyšels to příteli tam v nebes kůru?" [Do you hear [my friend] there in heaven's choir?”]. The incipit of Zdeněk's theme first appears in the accompaniment, second system, first bar. Milada, "Radostí nesmírnou," [Infinite joy] (Dalibor, Act II, scene vi, beginning on p. 89). Both of these examples may have been intended to refer to Leonore's aria "Abschleulicher!" in Fidelio. However, they bear the unmistakable stamp of Smetana's personality as a composer.

${ }^{34}$ Miranda and Fernando in Bouře; Rusalka, "Mesičku na nebi hlubokém [Dear moon in the deep heavens], (Rusalka, Act I, p. 38) and the Prince's arias "Vidino divná přesladka, jsi-li ty člověk nebo pohádka?" [Strange, sweet phantom, are you human or something from a fairytale?] and "Vím, že jsi kouzlo, které mine a rozplyne se v mlžný rej” [I know that you are magical, and that you can vanish in the whirling mist] (Act I, beginning on p. 80 and 87, respectively). 
ple, Janáček published a feuilleton that anticipates aspects of Fibich's handling of dissonance in Bouře ${ }^{35}$ Since it was published after Boure was completed but before its première, it is very unlikely that it had any connection with Boure. In this feuilleton, Janáček observes the perception of dissonance is affected by other musical aspects, such as increased tempo, rhythm, orchestration, and dynamic level. Meticulous handling of these aspects can bring a specific dissonance into prominence or shift it to the background; customized figurations can refine the effect of dissonance.

The evolution of tectonics towards the end of the nineteenth century seems to have had a significant effect on all genres of Czech music. It can be observed in the transition from Dalibor, which still exhibits stylistic elements of French grand opera, to Jeji pastorkyña, where it provides a solid foundation for the entire work. But that observation is only a small part of a much larger analytical goal - to observe the stylistic changes and syntheses that characterize the remarkable era that followed Smetana, to discover the significance and power of late nineteenthcentury Czech music from a purely musical perspective.

Some of Fibich's achievements became particularly valuable through synthesis for the following generations of composers as they developed their own musical languages. They include: transcending tonality through unorthodox chord-progressions and flowing lyricism; melodic contours following the inflections of text and emotion rather than periodic form; using large form and inner content as relatively independent layers; an imaginative use of traditional structures such as sonata allegro form; direct communication through sound itself. Fibich's example also led to the recognition of the value of advanced professional training for Czech composers, and of the vital need for flexible analytical strategies to cope with the innovations of his era and of the twentieth century.

The excellent research and support of many Czech scholars have made this paper possible. I would particularly like to acknowledge the friendship and knowledgeable criticism of Jiří Kopecký.

The writings of Václav Štěpaň, Jiří Vysloužil, Karel Janeček, and Jaroslav Vogel provided the analytical foundation for this paper. My copies of Janeček's Tektonika [Tectonics] and Hudebni formy [Musical forms] belonged to émigré composer Miroslav Lebeda, who studied at the Prague Conservatory during World War II. According to Lebeda, Janeček's terminology for timbre, articula-

${ }^{35}$ Leoš Janáček, "Nový proud v teorie hudební” [A new current in music theory] in: Leoš Janáček. Teoretické dílo, v. 1, p. 186-7; originally published in Lidové noviny, November 1894. 
tion, pitch, etc. should refer to interdependent aspects of actual sound in performance, not merely a priori parameters for analysis. Janeček wanted to discover the quality of music, not merely establish its quantifiable measure.

I have also used vocal-piano scores that belonged to émigré soprano Lída Brodenová (1902-1990). Shortly after World War I, she attended a class taught by Leoš Janáček in which singers and composers were deliberately brought together to discuss vocal music. Her last use of these treasured, tattered scores was to convince me of the importance of Czech music and the beauty of the Czech language. Her love and understanding of these operas have influenced this paper.

\section{Cloud-Capped Towers: Tectonics in Fibich's Opera Bouře}

\section{Abstract}

The genre of opera has often provided a fertile context for the development of tectonics: inner structures designed to give coherence to a specific composition and to convey its content. The simplest applications of such structures in opera have consisted of clearly-defined, repetitive motivic references to characters and dramatic events. During the second half of the nineteenth century, these structures became increasingly more subtle, more comprehensive, and more responsive to compositional impulse and emotion. As musical subtexts, they intensified the theatrical immediacy of the work through evocation of mood, enhancement of text, gestures, and interrelationships. Notable examples of such subtexts can be found in Czech operas: Smetana's Dalibor, Dvořák’s Rusalka, Janáček’s Jeji pastorkyña, as well as Bouře.

Fibich's intensive professional training at the Leipzig Conservatory and his continual goal to achieve compositional excellence produced a mature style of unusual power, clarity and depth. His transition from simple motivic referentiality to a subtext of complex, expressive inner structure is especially visible in Boure. Musical evidence indicates that operas such as these influenced the growth of tectonics in Czech music well into the twentieth century.

\section{Nebetyčné věže: tektonika ve Fibichově opeře Bouře}

\section{Abstrakt}

Žánr opery často poskytoval plodný kontext pro rozvoj tektoniky: vnitřní struktury navržené tak, aby dávaly soudržnost konkrétní skladbě a vyjadřovaly její obsah. Nejjednodušší aplikace takových struktur v opeře sestávala z jasně definovaných, opakujících se motivických odkazů na postavy a dramatické události. Během 
druhé poloviny devatenáctého století se tyto struktury staly čím dál jemnějšími, komplexnějšími a citlivějšími na kompoziční impulsy a emoce. Jako hudební podtexty zesilovaly divadelní bezprostřednost díla prostřednictvím vyvolání nálady, podpory textu, gest a vzájemných vztahů. Pozoruhodné př́klady takových podtextů lze najít v českých operách: Smetanův Dalibor, Dvořákova Rusalka, Janáčkova Jeji pastorkyně i Bouře.

Fibichovo intenzivní profesionální školení na lipské konzervatoři a jeho neustálý cíl dosáhnout kompoziční dokonalosti vyprodukoval vyzrálý styl neobvyklé síly, jasnosti a hloubky. Jeho přechod od jednoduché motivické referenčnosti k podtextu složité, výrazné vnitřní struktury je viditelný zejména v Bouři. Hudební důkazy naznačují, že takové opery ovlivnily růst tektoniky v české hudbě až do dvacátého století.

\section{Keywords}

Zdeněk Fibich; Czech music; opera; opera Bouře [The Tempest]

\section{Klíčová slova}

Zdeněk Fibich; česká hudba; opera; opera Bouře

Judith Fiehler

judithfiehler@gmail.com 